Editorial

\title{
4th Edition of the International Autologous and Allogeneic Cell Therapy for Solid Tumors (ATST) Meeting
}

\author{
Marco Bregni ${ }^{1}$, Richard W. Childs ${ }^{2}$, Naoto T. Ueno ${ }^{3 凶}$
}

1. Department of Hematology, Istituto Scientifico San Raffaele, Milano, Italy

2. Hematology Branch, National Heart, Lung, and Blood Institute, National Institutes of Health, Bethesda, MD 20892-1202 USA

3. Department of Breast Medical Oncology, The University of Texas MD Anderson Cancer Center, 1515 Holcombe, Unit 1354, Houston, Texas 77030, USA

$\triangle$ Corresponding author: Prof. Naoto T. Ueno, Phone: 713-792-8754; Fax: 713-794-4385; E-mail: nueno@mdanderson.org

(c) Ivyspring International Publisher. This is an open-access article distributed under the terms of the Creative Commons License (http://creativecommons.org/ licenses/by-nc-nd/3.0/). Reproduction is permitted for personal, noncommercial use, provided that the article is in whole, unmodified, and properly cited.

Received: 2011.05.08; Published: 2011.05.23

\begin{abstract}
The fourth edition of the International Autologous and Allogeneic Cell Therapy for Solid Tumors (ATST) meeting was held in Venice, Italy, between March 31 and April 1, 2011.
\end{abstract}

Key words: Autologous and Allogeneic Cell Therapy, Solid Tumors

The fourth edition of the International Autologous and Allogeneic Cell Therapy for Solid Tumors (ATST) meeting was held in Venice, Italy, between March 31 and April 1, 2011. The ATST meeting was initially organized as a venue for learning the latest information related to the use of allogeneic transplantation for treating in solid tumors. As new immunological and targeted therapy approaches have been developed, the meeting has evolved to cover topics related to the use of novel cellular and antibody-based approaches for treating advanced solid tumors.

More than 20 world-renowned experts in the field of cellular and antibody-based tumor immuno-biology and autologous/allogeneic transplantation presented their latest data and discussed novel methods of potentiating immunity against cancer. The meeting was divided into multiple sessions addressing novel monoclonal antibody, immunotoxin, radio-immunoconjugates, and vaccine therapies for cancer as well as novel methods to augment NK-cell and T-cell-based antitumor immunity. The meeting also included sessions that updated the results of autologous and allogeneic transplants for solid tumors, as well as methods to enhance graft-vs-tumor effects utilizing tumor antigen-specific T-cells, alloreactive NK cells, and post-transplant tumor vaccine approaches.

This special issue of the Journal of Cancer includes a summary of each speaker's presentation from the ATST meeting.

This meeting was supported by an unrestricted educational grant. We thank the following sponsors for their support of this meeting:

- BIOREP Srl, ITALY

- CORONADO BIOSCIENCES Inc., USA

- FRESENIUS BIOTECH GmbH, GERMANY

- INNATE-PHARMA SA, FRANCE

- KYOWA HAKKO KIRIN Co. Ltd, JAPAN

- MEDAC GmbH, GERMANY

- MOLMED SpA, ITALy

- NOVARTIS FARMA SpA, ITALY

- PIERRE-FABRE ITALIA SpA, ITALY

- ROCHE SpA, ITALy 
We hope that you enjoy this special issue of the Journal of Cancer.

Marco Bregni, M.D., Department of Hematology, Istituto Scientifico San Raffaele, Milano, Italy; Chairman, EBMT Solid Tumor Working Party. Phone: 39-02-26434409; Fax: 39-02-26434760; E-mail: marco.bregni@hsr.it

Richard W. Childs, M.D., Senior Clinical Investigator and Chief, Section of Transplantation Immunotherapy; Captain, United States Public Health Service, Hematology Branch, NHLBI/NIH, Building 10 CRC, Room 3E5330, 10 Center Drive, MSC-1202, Bethesda, MD 20892-1202 U.S.A. (301) 451-7128; E-mail: childsr@nih.gov

Naoto T. Ueno, M.D., Ph.D., F.A.C.P., Professor of Medicine, Department of Breast Medical Oncology, Morgan Welch Inflammatory Breast Cancer Program, Department of Stem Cell Transplantation and Cellular Therapy; Chair, CIBMT, Solid Tumor Working Committee; The University of Texas MD Anderson Cancer Center, 1515 Holcombe, Unit 1354, Houston, Texas 77030. Phone: 713-792-8754; Fax: 713-794-4385;

E-mail: nueno@mdanderson.org 